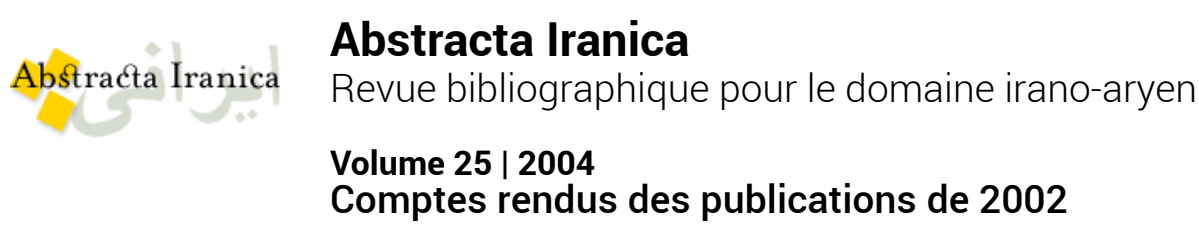

\title{
«The Beginning of Sasanian Coinage ». Bulletin of the Asia Institute 13, (1999), pp. 67-76.
}

\section{Aurélie Daems}

\section{(2) OpenEdition}

1 Journals

\section{Édition électronique}

URL : http://journals.openedition.org/abstractairanica/4327

DOI : 10.4000/abstractairanica.4327

ISSN : 1961-960X

Éditeur :

CNRS (UMR 7528 Mondes iraniens et indiens), Éditions de l'IFRI

\section{Édition imprimée}

Date de publication : 15 mai 2004

ISSN : 0240-8910

\section{Référence électronique}

Aurélie Daems, « «The Beginning of Sasanian Coinage ». Bulletin of the Asia Institute 13, (1999),

pp. 67-76. », Abstracta Iranica [En ligne], Volume 25 | 2004, document 87, mis en ligne le 15 mars 2006, consulté le 25 septembre 2020. URL : http://journals.openedition.org/abstractairanica/4327 ; DOI : https://doi.org/10.4000/abstractairanica.4327

Ce document a été généré automatiquement le 25 septembre 2020.

Tous droits réservés 
«The Beginning of Sasanian Coinage ». Bulletin of the Asia Institute 13, (1999), pp. 67-76.

\section{Aurélie Daems}

1 L'article donne un premier aperçu du projet Sylloge Nummorum Sasanidorum visant à la publication de collections de monnaies sassanides présentes dans divers musées. Ici l'A. traite l'action d'Ardashir qui, rompant en quatre phases successives avec les pratiques de la fin de l'époque parthe, parviendra à renforcer la qualité du numéraire tout en conservant les unités et fractions. L'atelier d'origine était à Istakhr, puis sera déplacé à Ctésiphon et à Ecbatane où seront émises les pièces avec le portrait du roi à la tiare au droit et l'autel au revers.

\section{INDEX}

Thèmes : 3.2.3. Séleucides, Parthes et Sassanides

\section{AUTEURS}

AURÉLIE DAEMS

Paris 